\title{
Local Security Management in Terms of a Country's Internal Security with Poland as an Example
}

\author{
Mariusz Kubiak \\ Siedlce University of Natural Sciences and Humanities, Faculty of Humanities \\ Żytnia 39 Street, 08-110 Siedlce, Poland \\ Robert Gawłowski \\ WSB University in Toruń, Faculty of Finances and Management in Bydgoszcz \\ Fordońska 74 Street, 85-807 Bydgoszcz, Poland \\ cross $^{\text {ref }}$ http://dx.doi.org/10.5755/j01.ppaa.16.3.19336
}

\begin{abstract}
The weakening role of national states in the international arena and increasing importance of cities at the economic and political levels gave rise to increased interest in the issue of local security. The aim of this paper is to present the way local security is organised and managed in the context of its functioning as part of Poland's internal security. It is concluded by indication of future directions of the development of security management.
\end{abstract}

Keywords: internal security, local security, community policing, public governance, public order, local authorities.

Raktažodžiai: vidaus saugumas, lokalinis saugumas, bendruomenès policija, viešasis valdymas, viešoji tvarka, vietos valdžios institucijos.

\section{Introduction}

Despite the swift and spectacular changes that have been taking place across the world from the 1990s, resulting in standardisation of the overwhelming majority of the spheres of the social-political and economic life and trans-national, international character of most threats, a state is still the fundamental entity in terms of security. It is a state that, while functioning in the international environment, has to ensure its sovereignty, both external and internal. Therefore, with certain reservations and limitations, it is fair to state that looking at a state's security based on the dichotomous division into external (international) security and internal (national) security it is still relevant and informative (has theoretical and pragmatic value). This is mainly due to the fact that a state exhibits features (attributes) of external and 
internal sovereignty, and as such, has to pursue both the external (foreign) and internal (domestic) policy. However, it should be noted, as emphasised by one researcher, that as a result of the new conditions, particularly in the aftermath of the terror attack of 11 September 2001, "the spheres of the internal and external security are not only tightly interlinked, but they also interpenetrate" [12, p. 14]. This is also the case with security threats: "The process of globalisation causes internal security threats to be located in various spheres of social and political life. These various economic, social, religious, environmental and IT threats are created by forces that work in conjunction with international players. Globalisation leads to the boundary between internal and external threats to security being blurred" [12, p. 18].

\section{Around the definition of internal security}

Academic literature shows numerous attempts to define internal security. One of narrower approaches proposes to "define (and understand) internal security as a state (process) achieved as a result of a state's fulfilment of its internal function, implemented as part of its strategic policy of security, in which people's health and life as well as national property are protected against unlawful acts, consequences of natural disasters and technical failures" [10, p. 29]. Meanwhile, referring to definitions formulated by experts in this field, J. Gierszewski makes the following, broader conclusions: "Internal security is a kind of security which refers to threats and their counteraction within a state. Ensuring a high level of internal security is a significant element of national security. Analysis of the definition of internal security shows that it is related to the state of stability and internal balance, the functioning of the structures within a state, decision-making processes and threats" [3, p. 16]. In still different perspective, aspiring to greater precision and clarity as stressed by the Author, a state's internal security is described "as such political-system-embedded state of the relationships and processes within a country that while ensuring effective and harmonious pursuing of the interests of the country and its citizens creates capabilities for efficient diagnosis and response in the event of emerging threats that undermine these interests" [2, p. 22]. At the level of law, internal security is regarded as an essential element of a state's security, as to guarantee it (along with external security and public order) is a task of the Polish government laid out in the Constitution of the Republic of Poland. The high social and political rank of internal security corresponds with the research position stating that it ensures "continuance, survival and development of an individual and social groups on the territory of a state" [9, p. 154]. Thus, in most general terms, internal security can be defined as such state of affairs and process that ensures internal permanence, stability and development of an entity. This entity, in the context addressed in this paper, is a state, understood as an autonomous political unit (organisation).

\section{Public, common and political (constitutional) security}

The scope of the meaning of internal security is wide. According to prevailing 
opinions, it comprises three types of security: public, common and political (constitutional). The first one, like the other two, is defined and understood in different ways. It can be, for instance, considered in a broader and narrower sense. In the first case, public security refers to "all the conditions and institutions that protect life, health, property of citizens and national wealth, political system and sovereignty of a state against phenomena that put at risk its social and legal order, that may undermine widely accepted standards of conduct", while in the second case - "a state in which citizens can freely exercise civil rights and liberties while respecting the common standards" [3, p. 19]. In turn, W. Fehler thinks that "public security is a lawdefined state existing in a country where conditions are ensured for efficient functioning of the state organisation pursuing common, supraindividual objectives, where there is effective enforcement of obligations and protection of the rights of the individuals living in such organisation (with special focus on life, health and property) and there are resources and implementation mechanisms in place that enable efficient response to situations compromising such state" [2, p. 43]. At the same time, the cited Author, by referring to the etymology of the terms "common" and "public", treats the concepts of "public security" and "common security" as synonymous, thus not seeing any point in the functioning of the latter. A concise, clear definition is proposed by A. Misiuk, according to whom public security should be understood as "a state where a state organisation is under no threats to its functioning and achievement of its interests, and can undergo a normal, free development" [6, pp. 16-17]. This definition corresponds with the position stating that the above-mentioned security "relates to a specific actual state that allows a state and its citizens to function in a normal way, a state that is connected with public threats to the state, its objectives, interests and political system" [12, p. 40]. Discussions on public security often involve the category "public order", which is organically connected with this issue. It is even claimed that these concepts appear together, complementing each other. From this perspective, "public order refers to the tasks and activities of public administration organs concerning compliance with standards and maintenance of the efficient operation of public institutions and amenities. Both these concepts are not equivalent or synonymous" [12]. Their scopes of meanings can both overlap and be divergent.

Another component of internal security, i.e. common security, still sparks many discussions and controversies in terms of its definition, which has already been suggested. Ensuring common security (rescue and protection of people) was included in the Strategy for National Security of the Republic of Poland from 2014. According to the content of this strategy, "the basic protection task involves activities connected with saving life, health, property and the environment from natural or man-made disasters and other local threats" [13, p. 40]. Academic literature accurately notices its connection with environmental security. They only differ in the subject of interest. The subject of common security is life and health of a human being, whereas that of environmental security is the state of the natural environment. In the draft Law on civil security, common security is equated with civil security. The authors describe it 
as "the state of the civilisation environment and natural environment in which citizens and their communities do not feel threat to their existence or basic life-related interests, as the state ensures formal, institutional and practical guarantees of protection leading to socially acceptable risk level. It is a process in which security entities ensure, at every organisational level, protection of life, health, property and the environment in emergency situations" [3, p. 21]. There is also an opinion that the relationship between common security and environmental security is that of submission. This is because environmental security and its threats become subject of interest only when they affect the human being. It is only then that they are noticed and given close attention, which visibly increases their significance. It is thus fair to say that common security is equated with environmental security impacting health and life of a human being [12, p. 41].

The last component of the internal security model adopted in this paper is political (constitutional) security. It is directly related to observation of law, and thus also the provisions of the Constitution. This Basic Law gives it high priority, regarding it as a highly important area of the functioning of the Polish state. It specifies citizens' obligations in the area of the defence of the state and allows for the possibility of declaring "extraordinary situation" states in the event of high threats: martial law, state of emergency, state of natural disasters. It also further specifies the list of the restrictions of freedoms, human rights and civil liberties in the event of declaring any of the emergency states. Recognising that the Constitution is the foundation on which a states legal order rests, it is reasonable to assume that the constitutional order is a set of principles according to which a democratic country based on the rule of law functions. Therefore, the following constatation seems logical: "Therefore, the protection of the authorities in a country, legal procedures of their election and ensuring conditions in which they function in uninterrupted way can be defined as protection of the constitutional order. From such perspective, this subject area is identified in close connection with a state's security" [10, pp. 40-41]. Academic literature highlights three basic elements of political security, which are permanent components of modern constitutions. These are: general principles equated with a country-adopted values determining the country's character; a system of a state's highest authorities along with their competences and mutual relationships (political regime, state system); a set of liberties and rights of a human being and a citizen. It is worth stressing the fact that unlike public and common security, political security is political in character [12, p. 41]. Thus, it is connected with exercising state authority, whereas public security and order have administrative (executive) character, and common security is focused around natural (health-related, environmental) issues.

\section{Essence and character of local security}

Based on the above theoretical considerations, the Authors assume that local security, as an element of a country's internal security, should be understood as a state of stability occurring in a certain territory (within the boundaries of a local 
government unit) which reflects the lack or presence of any threats to the normal functioning of the public administration organs as well as the lifestyle of the residents of a local community protected by these organs.

Since the period of changes to the political system in Poland (1989), the issues of local security have become more and more important in public discourse. Although this concept has appeared earlier while discussing the division into global, regional, subregional and local security, it should be stressed that in this context localness has only international reference. In the here-addressed narrower dimension which sees local security as an element of a country's internal security, this localness should be comprehended in the framework of a certain social order functioning on the basis of natural relationships and individual planes of contacts. It is worth stressing at this point that localness can also be defined as a certain ideology that defines the directions of local development. This development is basically connected with the initiative and activity of people who are members of a specific local community [11, p. 445]. Today's security challenges are gaining a new dimension due to a dynamic evolution of the role of modern states, increasing globalisation processes and the new character of the state-citizen relationship. In this context, we can see a growing importance of the issue of local security and related initiatives of prevention activities, community policing, i.e. getting citizens involved in security promotion activities. These processes are closely connected with departure from a state-centric way of thinking about security, although a state still retains a leading role in this respect. Nowadays, while writing about the issue of internal security it is difficult to omit the role fulfilled in it by local government units, which perform a range of tasks for their residents in almost every area of the functioning of a state. A commonly accepted standard of a democratic state based on the rule of law is the functioning of a local government. Pursuant to the Constitution of the Republic of Poland, the territorial system ensures decentralisation of public authorities by establishment of a local government that performs part of public tasks in its own name and on its own responsibility. This form of a state's organisation aims to implement the constitutional principle of subsidiarity and ensure that citizens co-participate in the exercise of public authority. A local government as a corporation with legal personality the territory of which is inhabited by local or regional community embodies the principles of the general good remaining at the same time part of a state.

\section{Coordination of local security at the national level}

Local security is implemented at three levels of public governance. First of them refers to national level coordination of activities undertaken by local government units. The body responsible for these issues is the Ministry of Internal Affairs and Administration. The instruments used by the minister responsible for internal security is the inter-ministerial Team for Cooperation with Municipal (City) Guards. It operates based on the regulation no 28 of the Prime Minister dated 19 April 2017. It is composed of representatives of local government units represented by Polish-wide local government corporations, a representative of the General Police Headquarters of 
Poland and the national representation of municipal guards. The team is led by the deputy minister for internal affairs. Its tasks include the development and recommendation of the directions of cooperation between the Police, city guards and local government units; coordination of the cooperation of the central and local organs of government administration with the administration organs of local government in protection of public order, as well as consulting and preparing legal solutions in the area of security, including road traffic security. The second field of activity of the minister responsible for public security in the area of local security is development of good practices of activities in the area of local security. It is implemented through the government programme "Safety united". Its aim is to financially support activities promoting security in public places, with particular focus on the establishment of local security systems; counteract pathologies and protect children and youth as well as providing education to increase security. Another example is the programme of Certification of Municipal (City) Guards, which is designed to popularise good practices in the area of the organisation and functioning of groups responsible for public order on the territory of a commune or cooperation with the European Crime Prevention Network (EUCPN). The above-listed activities significantly complement the statutory tasks and competencies of the minister responsible for public administration connected with the supervision of the services responsible for security (Police forces, Border Guards) and the initiative of proposing legal changes designed to improve security in the country.

\section{Local security from the perspective of local government units}

The second level of local management of security is local government units that function within the framework of the basic territorial division of the country. In the three-level structure of local governments in Poland, performance of public tasks at the local level, including those connected with public security and order, is the responsibility of commune and poviat authorities. The organisation and functioning of the most important institutions responsible for ensuring security (i.e. the Police) are subject to supervision and control by government administration bodies, with local governments having some power in this respect. Local authorities can and should act in support of security, mainly through prevention of threats by eliminating their potential causes [4]. In the case of the basic local government unit, i.e. commune, such prevention includes implementation of the tasks specified in the law on public gatherings and mass events (connected with issuing permits for holding a public gathering and mass events and ensuring protection to its participants for their duration); law on flood protection (maintenance of flood protection); law on education in sobriety and prevention of alcoholism (issuing permits for retail sale of alcoholic beverages); law on regional planning (drawing up a local development plan and issuing decisions on construction permit) or law on road traffic (organisation of road traffic in the territory of local government units). Apart from the above-listed public-authority activities, local government units at the commune level also perform a range of non-public-authority initiatives. They take the form of activities aimed at 
the development of plans (e.g. plans for the prevention of alcoholism and drug abuse, plans for security at schools) or supporting initiatives of other non-governmental institutions, which fulfil preventive and informative role.

Of particular importance in terms of ensuring public security and order in a commune is the possibility of the establishment of municipal (city) guard by the municipal council. It is one of the forms of the implementation of a commune's own task regarding the assurance of public order as assigned to it by the law on communal authority. Municipal guard functions are based on the Law of 29 August 1997 on municipal guards, which regulates the basic tasks and competences of this organ as well as the scope of the competences of municipal guard officers. It has an ancillary role with respect to local community through ensuring peace and order in public places, control of road traffic, public transportation and cooperation with relevant entities in the rescue of citizens' life and health, protection of amenities and public utility facilities as well as informing local community about the state and types of threats. In order to implement the above-indicated tasks, municipal guard officers are authorised to give instructions, check people's identity papers in justified cases to establish their identity, apprehend people who clearly pose direct threat to life or health as well as perform personal checks and use direct coercion measures. The character of the functioning of this group is to a large extent determined by awareness and impact of local authorities, which define priorities of activity. Unfortunately, in many cases local authorities attached more importance to the tasks connected with road traffic control. It is highly likely that the motivation behind that was to obtain additional income, which led to lack of trust in the institution of municipal guard among local communities and demand for their liquidation.

The last category of activities in support of public security and order carried out at the local level is getting citizens involved in security-oriented actions. Polish law allows local communities to form various self-defence groups designed to ensure security, such as neighbourhood watch or vigilantes. It seems today that people's joint activity and cooperation between all institutions responsible for ensuring security is in what we should put the greatest hope in the near future as far as significant improvement of security in local communities is concerned [14]. This is because, on the one hand, it is not possible to continuously increase the degree of public institutions' involvement, while on the other hand, it is necessary to learn about the needs and preferences of local communities. This conviction was the basis for the formulation of the concept of community policing, the most important principle of which is public participation. We can distinguish two ways of initiating cooperation between the Police and local community. The first is bottom up and results from social initiative. Polish academic literature still lacks comprehensive studies that describe the scope and character of cooperation initiated in this way. The second way is top down cooperation, which is initiated by policemen as part of their duties. The most important element of the implementation of the idea of community policing in Poland is a community police officer, who is often a "first contact officer" for citizens. The work of these officers is very often an element of the image of the whole 
services and impacts the degree of trust in the Police among citizens. The development of relationships between local community and institutions responsible for ensuring public security and order should be seen as a long-term process that takes time, cooperation and positive experience. Therefore, it should not be perceived only in terms of single indicators. An element of support for efforts aimed at cooperation with the local community is the governmental programme "Commune police officers closer to us", developed by the Ministry for Internal Affairs and Administration.

The key role in the Polish system of local security is performed by poviat commissions responsible for security and order, which are an important element of the coordination of the activities of a local government, joint inspectorates and guards as well as the Police. The above-indicated commissions are a key part of activity in support of security which involves exchange of knowledge between partners, planning of public institutions' activity, and cooperation between the different sectors of administration, commercial and non-government actors, which should take place both in vertical (between the entities of various administrative levels) and horizontal terms (at a specified level). In this context, the functioning of institutions and partnerships at the local level is an important element of the creation of security systems as part of bottom up initiatives, which significantly complement and adapt the activities of central institutions shaping the system of public security as part of top down solutions adopted at the level of governmental administration. The functioning of the commission was defined in Art. 38a-c of the Law on district (poviat) government. Its fundamental aim is to ensure the possibility of implementing the tasks of the chief official of a district (starosta) in the area of order and security in the form of the authority over poviat services, inspectorates and guards. The legislature defined their tasks in the form of an exhaustive list imposing obligation on poviat authorities to assess threats to public order and security, issue opinions on the work of the Police, prepare a draft of a poviat programme for crime prevention and ensuring public order and the safety of citizens', issue opinions on other programmes for cooperation between the police and other poviat services, inspectorates and guards, as well as a draft budget, draft laws and other issues connected with security and order.

For co-ordination of the above-indicated duties, appropriate composition of the members involved in the commission's works is established. They include, apart from poviat authorities or authorities of a city on poviat laws (i.e. starosta and two councillors), public prosecutors designated by the competent district public prosecutor, two representatives of the poviat Police headquarters designated by the Poviat Police Chief and three persons designated by the starosta from among people with outstanding knowledge about the problems being the subject of the commission's works who are figures of authority and enjoy public confidence among the local community. They are, in particular, representatives of commune authorities, non-government organisations, education staff, and employees of institutions for countering social pathologies and unemployment prevention. As was noticed by J. Czapska, the functioning of poviat Commissions for Security and Order, which are de facto the only obligatory element of the coordination of local level activities in 
support of security as well as local partnerships, is often underrated [1]. The necessity of cooperation within poviat commissions arises directly from statutory provisions included in the law on poviat authorities. Some elements are of significant importance here, namely, statutory definition of: (1) the composition of the commission; (2) the Commission's tasks; (3) the starosta's possibility of demanding that the Police and other poviat services, inspectorates and guards provide documents and information on their work. As pointed out by A. Urban, the statutorily defined composition of the commission gives the starosta very wide possibilities of creating a forum for implementation of an integrated preventive programme - a preventive strategy on the territory of poviat [14]. The only comprehensive study presenting their achievements is a study conducted by Police Academy in Szczytno [7] and a scientific publication which was an effect of the work of a research team led by Professor J. Czapska [1].

Apart from the above-indicated competences in the area of coordination of the activities of the services responsible for public security and order, the implementation of poviat tasks designed to enhance security is also important. They include, among other, the obligation to assess the state of flood safety; cooperation with the State Fire Brigade with respect to the functioning of the National Rescue and Fire Fighting System, as well as a range of tasks connected with social security implemented by poviat employment offices and welfare institutions; public transportation, road management and environmental protection and nature conservation. Provisions of the law on poviat authorities grant the starosta (the executory organ of poviat authorities) a right to undertake necessary activities within the scope of poviat authority competences with regard to a threat to public interest, direct threat to health and life and in matters that can potentially cause significant material losses and in urgent matters.

It is thus fair to say that poviat authorities do not execute tasks directly connected with public security, but they have a significant role in coordination of the activities of the institutions that constitute government organisation and deal with such matters. This state of affairs is negatively evaluated by many researchers, as local societies do not have sufficient impact on the level of security. It is, however, worth mentioning that the fact that poviat authorities have mainly coordination competences does not mean that they are ineffective. Development of a programme for crime prevention and protection of public security and order as well as the possibility of providing financial support for implementation of such activities to services directly responsible for security (State Fire Brigade and the Police) can be an effective tool for building the culture of local security. The key role in this respect is played by the knowledge and skills of a starosta in the area of public security.

\section{Social participation for the benefit of security}

The third level of security management refers to cooperation of public administration organs and services responsible for public security and order with nongovernmental organisation and residents. Systematic contact between the abovementioned actors is of particular importance in the case of security. Without 
partnership of local society, it will not be possible to effectively prevent and detect crime, and the role of the Police will be limited to crime investigation. Global experiences connected with reforms to police operation show that their common element is wide cooperation with society, in particular with the local community [5]. They involve departure from a top down imposition of the reforms to the functioning of the police in favour of building bottom up cooperation mechanisms. Building security, including local security, based on national institutions seems to be widely regarded as anachronism today [25]. The concept of community policing, although it appears nowadays with practically all security programmes, indicates a permanent trend in the way institutions responsible for security function, i.e. their opening up to the social environment. Moreover, the departure from hierarchic ways of public governance in favour of participation and network models is currently a universal paradigm, also in other areas of management of public services.

Accepting the above assumption, it is fair to say that an element that complements but also constitutes a system of local security is cooperation between local authorities and non-governmental organisations. Such possibility is provided for in the law on public benefit and voluntary service, which specifies, among other things, the most important legal institutions in the area of cooperation between nongovernmental organisations and public administration organs. They include such issues as assignment of public tasks to non-governmental organisations, co-funding of their activity, and the functioning of a public benefit council as an element of crosssectoral dialogue. The practice of the functioning of non-governmental sector in Poland shows that organisations dedicated to security issues represent substantial minority. According to data from studies into this sector [8], they account for less than $5 \%$ of all the functioning organisations. Sport, tourism and recreation organisations constitute the largest group (34\%) followed by education organisations $(15 \%)$. It is thus fair to say that such activities have only an indirect impact on the level and sense of security.

An important element of the functioning of public administration, including administration responsible for security, is the dynamically changing social environment. In particular, the key factor is the Internet and modern methods of communication, which allow members of local communities to have a direct impact on the way public tasks are executed. This is also increasingly recognised by representatives of local authorities. It is evidenced by the development of technological solutions designed to organise public communication and participation. Reporting about threatening situations or violation of public order - these are just some of the purposes for which mobile applications can be used. An example showing change in the way of perceiving the role of residents in local security using the Internet is the initiative by municipal authorities of Warsaw, which systematically hold competitions for resident-developed applications - danepowarszawsku.pl. The winner of the last edition of the project was an application that enables residents to report threatening events. The area of residents' activity addressed in this paper still remains an issue that has not been examined by those dealing with security and is a 
research proposal for the future. The above-indicated practices of involving local communities in local security management are also confirmed by experiences of European cities. The change to the paradigm of public administration management, in particular local government units, in the spirit of governance and sharing cities refers fundamentally to active involvement of local community in co-production of public services.

\section{Conclusion}

1. Local security has become increasingly important in recent years. This is due to the fact that national states lose importance in the international arena, with growing importance of international organisations. An important factor is also the dynamic development of metropolises and cities, which share knowledge and experience in public governance via transnational cooperation. One of such areas is local security. The above assumptions are confirmed by the way local security, as an increasingly important element of Poland's internal security, is organised and managed, as presented in the paper.

2. Local security is a type of security which is most often identified by citizens through their personal experiences verbalized in the form of expressions: my, your, his, our, their, personal security. In this context, it is not a distant abstraction, but a tangible, specific reality, that significantly impacts the level and quality of the everyday life of a modern human being. Dynamic transformations of the public administration environment, which have an impact on public governance, also affect the way local security is managed. This can be seen in the increasing importance of the third level of local governance - i.e. cooperation between public administration organs and local communities. Their role is not limited to reporting and providing information about the current situation, but also involves the development of tools designed to increase the quality of security management at the local scale.

\section{References}

1. Czapska, J. (ed.). Koordynacja działań lokalnych na rzecz bezpieczeństwa. Cracow: Jagiellonian University, 2014.

2. Fehler, W. Bezpieczeństwo wewnętrzne wspótczesnej Polski. Warsaw: Arte, 2012.

3. Gierszewski, J. Bezpieczeństwo wewnętrzne. Zarys systemu. Warsaw: DIFIN, 2013.

4. Lis, W. Bezpieczeństwo wewnętrzne i porzadek publiczny jako sfera działania administracji publicznej. Lublin: UMCS, 2015.

5. Minkina, M. Dylematy i mity bezpieczeństwa lokalnego. In: W. Fehler (ed.), Bezpieczeństwo w środowisku lokalnym. Warsaw: Arte, 2009.

6. Misiuk, A., Administracja porzadku publicznego i bezpieczeństwa publicznego, Warsaw: Academic and Professional Publishers, 2008.

7. MSWiA. Ministerstwo Spraw Wewnętrznych 2008. www.mswia.gov.pl [2017-07-12].

8. NGO. Portal Organizacji pozarzadowych 2017. www.Ngo.pl [2017-07-10]. 
9. Pokruszyński, W. Bezpieczeństwo. Teoria i praktyka. Jozefow: Publishing House of the Euroregional School of Economics, 2012.

10. Ścibiorek, Z., Wiśniewski, B., Kuc, R. B., Dawidczyk, A. Bezpieczeństwo wewnętrzne. Torun: Adam Marszałek, 2015.

11. Sosnowski, W. Rozwój społeczności lokalnych u schyłku XX wieku. In: R. B. Woźniak (ed.). Społeczności lokalne w perspektywie integracji europejskiej. Szczecin: University of Szczecin, 2000.

12. Sulowski, S. O nowym paradygmacie bezpieczeństwa $w$ erze globalizacji. In: S. Sulowski, M. Brzeziński (eds.). Bezpieczeństwo wewnętrzne państwa. Wybrane zagadnienia. Warsaw: Elipsa, 2009.

13. Ura, E., Pieprzny, S. Bezpieczeństwo wewnętrzne państwa. Rzeszów: University of Rzeszów, 2015.

14. Urban, A. Bezpieczeństwo społeczności lokalnych. Warsaw: Losgraf, 2011.

15. Ustawa z dnia 20 czerwca 1997 roku Prawo o ruchu drogowym, Dz. U. 1997 nr 98, poz. 602 z późn. zm.

16. Ustawa z dnia 20 marca 2009 roku o bezpieczeństwie imprez masowych, Dz. U. $2009 \mathrm{nr}$ 62, poz. 504 z późn. zm.

17. Ustawa z dnia 24 lipca 2015 roku Prawo o zgromadzeniach, Dz. U. 2015 poz. 1485

18. Ustawa z dnia 24 sierpnia 1991 roku o ochronie przeciwpożarowej, Dz. U. $1991 \mathrm{nr} 81$ poz. 351 z późn. zm.

19. Ustawa z dnia 26 października 1982 roku o wychowaniu w trzeźwości i przeciwdziałaniu alkoholizmowi, Dz. U. 1982 nr 35 poz. 230 z późn. zm.

20. Ustawa z dnia 27 marca 2003 o planowaniu i zagospodarowaniu przestrzennym, Dz. U. $2003 \mathrm{nr} 80$, poz. 717 z późn. zm.

21. Ustawa z dnia 27 sierpnia 1997 roku o strażach gminnych, Dz. U. 1997 nr 123 poz. 779 z późn. zm.

22. Ustawa z dnia 6 kwietnia 1990 roku o Policji, Dz. U. 1990 nr 30 poz. 179, z późn. zm.

23. Ustawa z dnia 8 czerwca 1998 roku o samorzadzie powiatowym, Dz. U. $1998 \mathrm{nr} 91$ poz. $578 \mathrm{z}$ późn. $\mathrm{zm}$.

24. Ustawa z dnia 8 marca 1990 roku o samorządzie gminnym, Dz. U. 1990, nr 16 poz. 95 z późn. zm.

25. Wisler, D., Onwudiwe, I. D. Community Policing: International Patterns and Comparative Perspective. New York: CRC Press, 2009.

Mariusz Kubiak, Robert Gawkowski

\title{
Lokalinis saugumo valdymas šalies vidaus saugumo kontekste: Lenkijos atvejo analizė
}

\author{
Anotacija
}

Susilpnèjęs nacionalinių valstybių vaidmuo tarptautinëje arenoje ir didejjanti miestų svarba ekonominiu ir politiniu lygiu sukèle didesni susidomèjimą vietos saugumo klausimais. Šio straipsnio tikslas - parodyti, kaip vietos saugumas organizuojamas ir valdomas, atsižvelgiant ị jo funkcionavimą kaip dalị Lenkijos vidaus saugumo. Tai daroma, nurodant 
būsimas saugumo valdymo plètros kryptis.

Mariusz Kubiak - Associate professor, Doctor with habilitation, Siedlce University of Natural Sciences and Humanities, Faculty of Humanities.

E-mail.: kubmar11@gazeta.pl.

Robert Gawtowski - PhD WSB University in Torun, Faculty of Finances and Management in Bydgoszcz.

E-mail.: robert.gawlowski@wsb.bydgoszcz.pl.

Mariusz Kubiak - habilituotas dakataras, docentas, Siedlcu Gamtos ir humanitariniu mokslų universitetas, Humanitarinių mokslų fakultetas.

E.paštas: kubmar11@gazeta.pl.

Robert Gawłowski - daktaras, Torunès aukštoji bankininkystės mokykla, Bydgoščiaus finansų ir vadybos fakultetas.

E.paštas: robert.gawlowski@wsb.bydgoszcz.pl.

Straipsnis įteiktas redakcijai 2017 m. birželio mèn.; recenzuotas; parengtas spaudai 2017 $\mathrm{m}$. rugsèjo mèn. 